\title{
EFL STUDENTS' STRATEGIES DEALING WITH COMMON DIFFICULTIES IN TOEFL READING COMPREHENSION SECTION
}

\author{
Iskandar Abdul Samad \\ English Education Department of Syiah Kuala University, Indonesia \\ Institute of Education Development and Quality Assurance of Syiah Kuala University, Indonesia \\ Email: iskandar.abdul.samad@unsyiah.ac.id \\ Miftahul Jannah \\ English Education Department of Syiah Kuala University, Indonesia \\ Email:emjiemial@gmail.com \\ Siti Sarah Fitriani \\ English Education Department of Syiah Kuala University, Indonesia \\ Email: ssfitriani@gmail.com
}

\begin{abstract}
TOEFL has been used as a requirement for non-native English students to pursue further study overseas, to get an appropriate job and to graduate from university. Students often encounter difficulties completing TOEFL reading test. This quantitative study investigates the undergraduate students' difficulties and their strategies in completing TOEFL reading comprehension test. The data was obtained by collecting students' worksheets of the TOEFL test and distributing questionnaires related to test taking strategies used by the students. Thirty students of English Education Department of Syiah Kuala University were involved as participants. The results indicate five difficult reading aspects encountered by the students. In addition, their strategies to complete the reading comprehension section of the TOEFL test are also found. These findings are further discussed in this paper.
\end{abstract}

Keywords: TOEFL reading comprehension, reading difficulty, reading strategy

\section{INTRODUCTION}

In many countries, such as Indonesia, English is considered as a foreign language. In this country, English is mostly used in English classrooms, while outside of the classroom, people commonly use their native language, Indonesian, for their daily communication. English is regarded as important foreign language. It is evident that this language is taught in junior high school until university. The ability of students mastering English is commonly seen from the result of English proficiency test that is Test of English as a Foreign Language (TOEFL). This test has been respected internationally (Warfield, Laribee, \& Geyer, 2013).
Nowadays, TOEFL is used to get scholarships in order to continue further study in English speaking countries. TOEFL is also used to apply for a job vacancy. The reliance on TOEFL has reached such a point that most domestic universities use this standardized test as a part of graduation requirements. The authority of universities set this precondition because they believe that TOEFL is able to evaluate students' ability and skills to understand English in academic tasks (Aliponga, 2013, p. 74).

At Syiah Kuala University, all students are obliged to pass the TOEFL test with a score between 450 and 475 the minimum (the score depend on the expectation of each faculty). This score is required prior to undertaking 
script or thesis final examination (Samad, Hizir, Kasim, Fitriani \& Mustafa, 2016). The type of TOEFL test that are required to undertake is a TOEFL prediction, which is a paper-based test that consists of listening, structure and written Expression, and reading comprehension sections. It is commonly understood that to achieve high score in the TOEFL test, students are expected to be able to answer questions of the three sections.

Achieving high score for this test is not an easy task. This is evidence in the work of Samad and Fitriani (2016). They find that most students of this university fail to achieve a required score to graduate from their study. They found tht among 1916 TOEFL test takers at Syiah Kuala University, only 53 students are able to achieve TOEFL score of 450-497, or $2.77 \%$. This result has shown that most students at Syiah Kuala University still cannot achieve the TOEFL requirement. Furthermore, a study conducted by Abboud and Hussein (2011) suggest that the difficulty in reading comprehension section of TOEFL experienced by test takers is due to the limited time they have during the test, and lack of knowledge in reading aspects.

Other studies have focused on the TOEFL test in general and problems in reading section of the test. While this study is an expansion of those previous studies, which focuses on the most difficult aspects of this section and also investigating strategies used by students.

\section{LITERATURE REVIEW Reading Comprehension}

A number of definitions of reading has been provided in literature. Reading can be defined as an interaction between readers and texts (Alderson, 2000; Klinger, Vaughn, \& Boardman, 2007) that contributes to automaticity and reading fluency (CelceMurcia, 2001, p. 154). Reading is important in education because this skill can provide students knowledge (Fjeldstad, 1994, p. 20). To get knowledge, students need to pass the process of meaning construction (Snow, 2002, p. 134). The meaning construction process leads to a comprehension. Students comprehend a text only when they understand the information in the text (Fitriani, 2015). Therefore, reading comprehension can be defined as the understanding of the written word and of the content being read in a text (Healy, 2002; Harrison, 2004; Ali, 2012).

\section{Reading Difficulties and Strategies}

The literature has reported many students find reading difficult because of several factors, one of them is their lack of ability to understand a particular text (Ali, 2012, p.5). Their limitation of vocabulary and some phrases could hinder them from understanding the meaning of English texts (Fitriani, 2015). This impacts on the students' ability in answering questions in reading comprehension section of TOEFL test (Antoni, 2014).

In a study conducted by Alghail and Mahfoodh (2016), there is a number of difficulties encountered by foreign students in a Malaysian university. The difficulties are in paraphrasing, note-taking, supporting ideas and managing the time for the reading test. Another researcher, Chawwang (2008) states that the most critical problems are in identifying difficult words, topic, the main idea of the passage, and lack of vocabulary. Similar research has been conducted by Nezami (2012) in EFL Saudi learners. In her research, she finds that their students are difficult to comprehend the text due to limited knowledge and skills.

To overcome the difficulties, there are some reading strategies commonly used to comprehend the information given in the text, for example summarising, question generating, skimming, scanning, etc (Phillip, 2003). Language learners could use any strategies to comprehend the texts. Reading strategies are very important, it is not only to successfully comprehending the text but also to overcome any reading problems 


\section{TOEFL Test}

TOEFL is highly recognized language testing in English which is internationally recognized and respected (Warfield, Laribee \& Geyer, 2013). TOEFL is used to evaluate the English proficiency of foreign language learners (ETS, 2006, p. 3). With TOEFL test, one could know the English proficiency of students whose English is not their native language. Nowadays, TOEFL is used in many occasions, for instance, those applying for scholarships to continue their study in the English spoken countries. Furthermore, this test is also needed by those who want to apply for a job both in home country and overseas. Even, this test is obliged by universities in Indonesia as a requirement to complete their study and obtain their bachelor certificate (Samad, 2016).

\section{Aspects and Skills in TOEFL Reading Section}

There are a number of aspects and skills to comprehend the reading text of TOEFL test. According to Phillips (2003), there are five aspects of TOEFL reading comprehension that consist 13 skills. First, questions about the ideas of the passage. This aspect consists of two skills: answering main idea questions correctly and recognizing the organization of ideas. Secondly, directly answered questions. This aspect consists of three skills: answering stated detail questions correctly, finding unstated details, and finding pronoun referents. Thirdly, indirectly answered questions. This aspect consists of two skills, these are responding to implied and transition questions. The fourth is vocabulary questions which consists of four skills, these are finding out meanings from structural clues, finding word parts, giving meaning for difficult and simple words by using context. Lastly, reviewing questions. This aspect consists of the ability to search for specific information, the tone, purpose, or course.

This study focuses on the most difficult parts of reading aspects faced by students at
Syiah Kuala University, and the strategies that they mostly use in a test.

\section{METHODOLOGY}

This is a descriptive quantitative study which focuses on understanding students' difficulties and strategies to deal with TOEFL reading comprehension. To collect the data, the researchers gave a TOEFL reading comprehension test. This test was given to figure out the most difficult aspects and skills in the reading section. The test was taken from Longman paper-based TOEFL preparation. Then, the researchers provided questionnaires to find out the strategies they commonly use to deal with the reading difficulties. The questionnaire items were adapted from Karbalaei (2010, pp. 67-68), Shang, Li and Wang (2010) and some were developed by the researchers.

The test and questionnaires were given to thirty undergraduate students studying at the English Education Department of Syiah Kuala University batch 2011. These samples were chosen purposevely.

The researchers analysed the data from the test using the lists of aspects and skills in reading comprehension. While for questionnaires, the scoring was using 4-point Likert scale.

\section{FINDINGS and DISCUSSION Result of the Test}

The following table presents the result of data from the test that is the percentage of each skill.

Table 1: Test Result

\begin{tabular}{lllll}
\hline Aspect & Skills & Total & \% \\
\hline \multirow{4}{*}{ I } & 1. & $\begin{array}{l}\text { Answering main } \\
\text { idea questions }\end{array}$ & 92 & 11 \\
& $\begin{array}{l}\text { correctly. } \\
\text { 2. }\end{array}$ & $\begin{array}{l}\text { Recognizing the } \\
\text { organization of } \\
\text { ideas. }\end{array}$ & 57 \\
\hline II & 3. & $\begin{array}{l}\text { Answering } \\
\text { stated detail }\end{array}$ & 116 & 14 \\
\hline
\end{tabular}




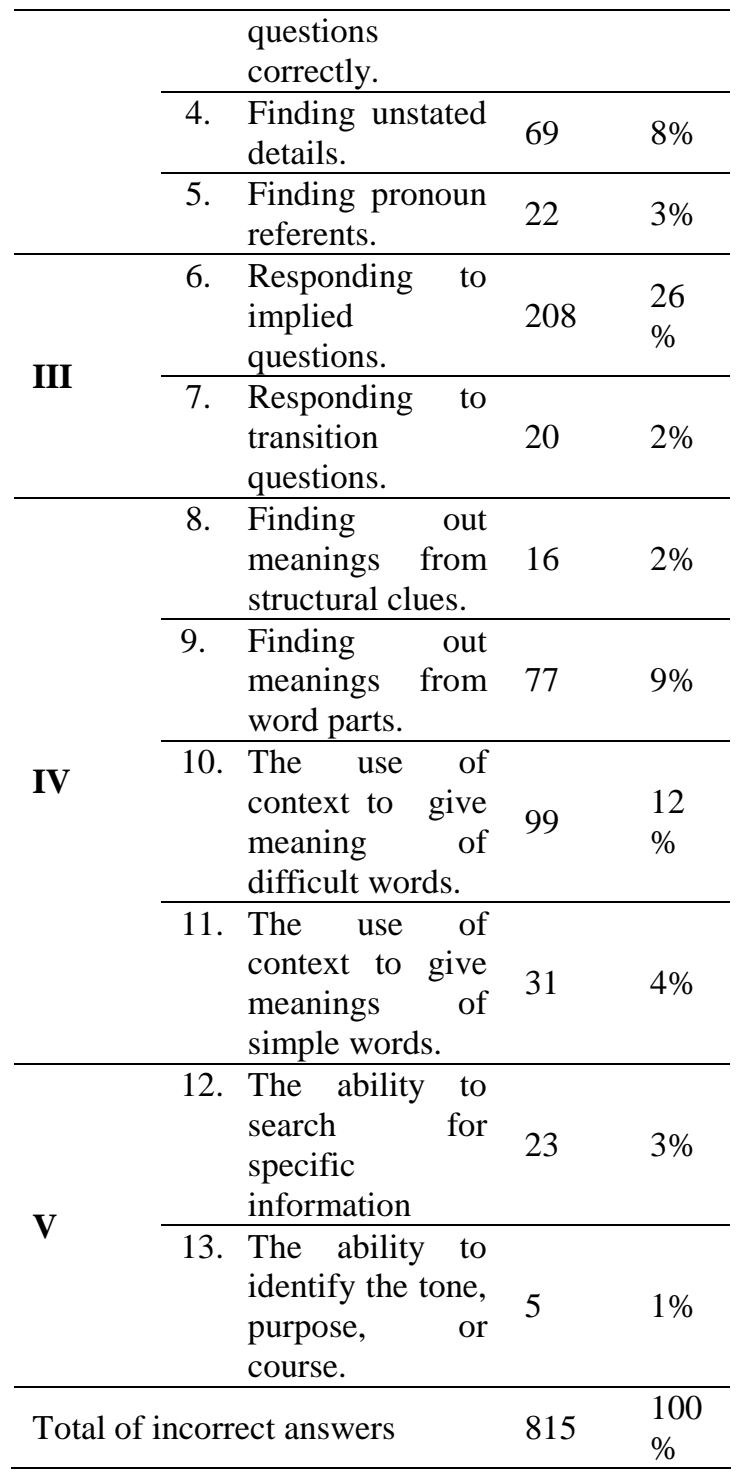

The table 1 above shows the skills that are considered to be the most difficult ones in TOEFL reading, which is skill 6 . This skill is identifying implied detail questions correctly. It is the highest percentage $(26 \%)$ of all that students answer incorrectly.

Then, it is followed by skill 3 (14\%), which is identifying stated detail questions correctly. It is the second most difficult skill for the students. The third most difficult skill is skill 10. It is the question about determining meanings of difficult words by using context which achieves $12 \%$ of the total incorrect answers.
Next, skill 1 is considered to be the fourth most difficult skill in TOEFL reading comprehension. The questions are about identifying the main idea correctly which is counted $11 \%$ of the total incorrect answers. Then, the fifth most difficult skill in TOEFL reading comprehension is skill 9, which is consisting the questions about determining meanings from word parts. students made $9 \%$ of the total incorrect answers.

\section{Results of Questionnaire}

The following table presents the strategies that students implement to deal with the reading comprehension difficulties. This result is presented based on the data obtained from the questionnaire fulfilled by the students.

Table 2. Questionnaire

\begin{tabular}{|c|c|c|c|c|c|}
\hline \multirow{9}{*}{$\begin{array}{l}\mathrm{N} \\
\mathrm{O}\end{array}$} & \multirow{9}{*}{ Statements } & \multicolumn{3}{|c|}{$S$} & \multirow{3}{*}{ A } \\
\hline & & \multirow{3}{*}{$\begin{array}{l}\mathrm{N} \\
\mathrm{e}\end{array}$} & \multicolumn{2}{|l|}{ o } & \\
\hline & & & $\mathrm{m}$ & $\mathrm{O}$ & \\
\hline & & & $\mathrm{e}$ & $\mathrm{f}$ & \multirow{2}{*}{$\begin{array}{l}\text { l } \\
\text { w }\end{array}$} \\
\hline & & $\mathrm{v}$ & $\mathrm{t}$ & $\mathrm{t}$ & \\
\hline & & $\mathrm{e}$ & $\mathrm{i}$ & $\mathrm{e}$ & $\mathrm{a}$ \\
\hline & & $\mathrm{r}$ & $\mathrm{m}$ & $\mathrm{n}$ & $\mathrm{y}$ \\
\hline & & & $\mathrm{e}$ & & \\
\hline & & & $\mathrm{S}$ & & \\
\hline \multirow{2}{*}{1} & \multirow{2}{*}{$\begin{array}{l}\text { I use key words to } \\
\text { search for main idea }\end{array}$} & 3 & 40 & 23 & 33 \\
\hline & & $\%$ & $\%$ & $\%$ & $\%$ \\
\hline \multirow{2}{*}{2} & \multirow{2}{*}{$\begin{array}{l}\text { I skim or can the text } \\
\text { to search for the idea. }\end{array}$} & 3 & 20 & 40 & 37 \\
\hline & & $\%$ & $\%$ & $\%$ & $\%$ \\
\hline \multirow{3}{*}{3} & \multirow{3}{*}{$\begin{array}{l}\text { While reading, I have } \\
\text { a purpose in mind and } \\
\text { try to focus on what I } \\
\text { read in the passage. }\end{array}$} & & & & \\
\hline & & 10 & 20 & 50 & 20 \\
\hline & & $\%$ & $\%$ & $\%$ & $\%$ \\
\hline \multirow[b]{2}{*}{4} & \multirow{2}{*}{$\begin{array}{l}\text { I use my background } \\
\text { knowledge whenever } \\
\text { I read a text. }\end{array}$} & & & & 17 \\
\hline & & $\begin{array}{l}3 \\
\%\end{array}$ & $\begin{array}{l}50 \\
\%\end{array}$ & $\begin{array}{l}30 \\
\%\end{array}$ & $\%$ \\
\hline \multirow{2}{*}{5} & \multirow{2}{*}{$\begin{array}{l}\text { I use prediction skill } \\
\text { while I am reading a } \\
\text { text }\end{array}$} & 10 & 47 & 30 & 13 \\
\hline & & $\%$ & $\%$ & $\%$ & $\%$ \\
\hline \multirow{4}{*}{6} & \multirow{4}{*}{$\begin{array}{l}\text { Focusing on } \\
\text { important } \\
\text { information in a text } \\
\text { through skimming a } \\
\text { whole text. }\end{array}$} & & & & \\
\hline & & 0 & 30 & 33 & 37 \\
\hline & & $\%$ & $\%$ & $\%$ & $\%$ \\
\hline & & & & & \\
\hline \multirow{3}{*}{7} & \multirow{3}{*}{\begin{tabular}{lr}
\multicolumn{2}{c}{ guess a meaning of } \\
a text & through \\
activating & my
\end{tabular}} & & & & \\
\hline & & $\begin{array}{l}3 \\
0\end{array}$ & 23 & 53 & 20 \\
\hline & & & & & \\
\hline
\end{tabular}




\begin{tabular}{|c|c|c|c|c|c|}
\hline & $\begin{array}{l}\text { background } \\
\text { knowledge }\end{array}$ & & & & \\
\hline 8 & $\begin{array}{l}\text { I make a literal } \\
\text { translation. }\end{array}$ & $\begin{array}{l}10 \\
\%\end{array}$ & $\begin{array}{l}20 \\
\%\end{array}$ & $\begin{array}{l}40 \\
\%\end{array}$ & $\begin{array}{l}30 \\
\%\end{array}$ \\
\hline 9 & $\begin{array}{l}\text { I read in details to } \\
\text { answer questions. }\end{array}$ & $\begin{array}{l}3 \\
\%\end{array}$ & $\begin{array}{l}20 \\
\%\end{array}$ & $\begin{array}{l}40 \\
\%\end{array}$ & $\begin{array}{l}37 \\
\%\end{array}$ \\
\hline 10 & $\begin{array}{l}\text { I use context clues to } \\
\text { understand the } \\
\text { meanings } \\
\text { vocabulary }\end{array}$ & $\begin{array}{l}0 \\
\%\end{array}$ & $\begin{array}{l}13 \\
\%\end{array}$ & $\begin{array}{l}47 \\
\%\end{array}$ & $\begin{array}{l}40 \\
\%\end{array}$ \\
\hline 11 & $\begin{array}{lr}\text { I guess } & \text { from } \\
\text { (suffixes, } & \text { prefixes) } \\
\text { and } & \text { semantic } \\
\text { knowledge } & \\
\text { (synonym, antonym) } \\
\text { to understand } \\
\text { unfamiliar } \\
\text { vocabulary }\end{array}$ & $\begin{array}{l}13 \\
\%\end{array}$ & $\begin{array}{l}40 \\
\%\end{array}$ & $\begin{array}{l}37 \\
\%\end{array}$ & $\begin{array}{l}10 \\
\%\end{array}$ \\
\hline 12 & $\begin{array}{l}\text { I keep reading a text } \\
\text { even I find some } \\
\text { difficult words in the } \\
\text { text. }\end{array}$ & $\begin{array}{l}3 \\
\%\end{array}$ & $\begin{array}{l}30 \\
\%\end{array}$ & $\begin{array}{l}50 \\
\%\end{array}$ & $\begin{array}{l}17 \\
\%\end{array}$ \\
\hline 13 & $\begin{array}{l}\text { I read questions prior } \\
\text { to reading a text. }\end{array}$ & $\begin{array}{l}0 \\
\%\end{array}$ & $\begin{array}{l}17 \\
\%\end{array}$ & $\begin{array}{l}40 \\
\%\end{array}$ & $\begin{array}{l}43 \\
\%\end{array}$ \\
\hline 14 & $\begin{array}{l}\text { When text becomes } \\
\text { difficult, I repeat } \\
\text { reading text to } \\
\text { increase } \\
\text { understanding even } \\
\text { when I find it } \\
\text { difficult. . }\end{array}$ & $\begin{array}{l}7 \\
\%\end{array}$ & $\begin{array}{l}30 \\
\%\end{array}$ & $\begin{array}{l}20 \\
\%\end{array}$ & $\begin{array}{l}43 \\
\%\end{array}$ \\
\hline
\end{tabular}

The table 2 above shows that the questionnaire item number one indicates that $40 \%$ of students admits if they sometimes use key words to search for main idea. The statement number two reveals that $40 \%$ of the students often skim or scan the text to search for the idea. $50 \%$ students often have a purpose in mind and try to focus on what they read in the passage while reading which is evidenced by the third statement.

Based on the statement number four, it can be seen that $50 \%$ students sometimes use their background knowledge whenever they read a text. Then, the students whose sometimes use their prediction skills to understand what is going to happen while reading a text, reaches about $47 \%$. It also appears in the next statement that $37 \%$ students always focusing on important information in a text through skimming a whole text. Related to the statement stated in number seven, it can be seen that $53 \%$ students often guessing a meaning of a text through activating their background knowledge. Then, they also often make a literal translation. It is proven by $40 \%$ of students in questionnaire number eight. For statement number nine, it shows that $40 \%$ of students often read in details to answer questions. They often read a text repeatedly to understand it.

Regarding to the statement number 10 , it can be seen that $47 \%$ students often use context clues to understand the meanings of vocabulary. Next, to understand unfamiliar English words, they sometimes divide it into parts that they understand and guess from suffixes, prefixes and semantic knowledge. It is agreed by $40 \%$ of the students in statement number 11. It also can be seen from questionnaire number 12 that $50 \%$ of students often keep reading a text even they find some difficult words in the text. In the questionnaire number 13, it appears that $43 \%$ of students always read questions prior to reading a text. They assume that reading the questions prior to reading texts could help them guess for the correct answers. Lastly, the last number of the questionnaire, which is item 14 reveals that when the text becomes difficult, they always repeat reading the text to increase their understanding It is proven by $43 \%$ of students who feel the same about it.

\section{DISCUSSION}

Reading is considered as essential skills for students. The students are required to have sufficient knowledge and skills to succeed in TOEFL test. The students are required to be aware of their ability in mastering reading aspects and skills in TOEFL to succeed the test. Knowing appropriate reading strategies could help them dealing with their difficulties in TOEFL reading skills.

As mentioned earlier, this study is to find out the most difficult skills encountered by the students in TOEFL reading section and 
possible strategies that may be used by them to deal with these difficulties. The researchers discuss these two purposes in a separate headings.

1. The most difficult skills in TOEFL Reading Comprehension Section faced by students batch 2011 at the English Education Department of Syiah Kuala University.

The data presented earlier reveal that there are five most difficult skills in reading section. The level of difficulties is shown by the percentage of each skill. Five most difficult skills are experienced by the thirty undergraduate students These five skills can be seen clearly in the following table.

Table 3. The most difficult skills in TOEFL Reading Comprehension

\begin{tabular}{|c|c|c|c|}
\hline Aspect & Skills & Total & $\%$ \\
\hline III & $\begin{array}{l}\text { \#6: Answer implied detail } \\
\text { questions correctly. }\end{array}$ & 208 & $\begin{array}{l}26 \\
\%\end{array}$ \\
\hline II & $\begin{array}{l}\text { \#3: Answer stated detail } \\
\text { questions correctly. }\end{array}$ & 116 & $\begin{array}{l}14 \\
\%\end{array}$ \\
\hline IV & $\begin{array}{l}\# 10: \text { The use of context to } \\
\text { give meanings of difficult } \\
\text { words. }\end{array}$ & 99 & $\begin{array}{l}12 \\
\%\end{array}$ \\
\hline I & $\begin{array}{l}\text { \#1: Answer main idea } \\
\text { questions correctly. }\end{array}$ & 92 & $\begin{array}{l}11 \\
\%\end{array}$ \\
\hline IV & $\begin{array}{l}\text { \#9: Determine meanings } \\
\text { from word parts. }\end{array}$ & 77 & $\begin{array}{l}9 \\
\%\end{array}$ \\
\hline \multicolumn{2}{|c|}{ Total of Incorrect Answers } & 815 & $\begin{array}{l}10 \\
0 \\
\%\end{array}$ \\
\hline
\end{tabular}

From the Table 3 , it is obviously seen that the most difficult skill in TOEFL reading comprehension section for the students is skill \#6, it is followed by skill \#3, \#10, \#1 and \# 9.

A study conducted by Chawwang (2008) shows some similarities that the most critical problems were in identifying difficult words, topic, the main idea of the passage, and lack of vocabulary. These problems make students unable to guess the meaning and to understand a text In addition, a study conducted by
Alghail and Mahfoodh (2016) also shows some similarities in which foreign students in a Malaysian university are experiencing difficulties in parapharing of their note takings.

Then, Mahmud (2014), in her study, shows that students' lack of skills and motivation hinder them from being able to comprehend a text. The result of research conducted by Antoni (2014) also reveals that in reading section, students face difficulties to understand the meaning of the passage and they could not catch all ideas from the passage given. According to her, the problems arise due to their limitation of vocabularies, some phrases, and time available for the section.

Interestingly, our study extends the findings of previous studies conducted by Alghail and Mahfoodh (2016), Mahmud (2014), Antoni (2014), Chawwang (2008) and Samad and Fitriani (2016). In our study, we reveal more problematic skills for students, which are: (1) identifying implied detail questions correctly, (2) identifying stated detail questions correctly, (3) determining meanings of difficult words by using context, (4) identifying main idea questions correctly, and (5) determining meanings from word parts.

\section{The strategy used by students batch 2011 at English Education Department of Syiah Kuala University in improving their Reading Skills in TOEFL Preparation Test.}

As data presented earlier, the strategies used by the students are varied. The frequencies appear in each statement are different. The strategies selected by the students are mentioned in statement number 2 , $3,7,8,9,10$, and 12 , which are only a half of the total strategies.

Antoni (2014) reveals that most of students agree that strategies on completing TOEFL are very important to succeed the test. Lacking strategies, such as the ability to do scanning and skimming, leads to major 
problems in comprehending reading text (Nezami, 2012)

\section{CONCLUSION}

TOEFL as an international test is commonly used to measure the level of students' competence in mastering English. This test is important to apply for a scholarship, a job and to graduate from university. To achieve these expectations, students need to know the difficulties they might encounter undertaking this test; so, they are aware of some strategies that can help them reduce their difficulties. Students are required to apply some strategies to deal with the TOEFL difficulties.

\section{REFERENCES}

Abboud, Z. A. R., \& Hussein, N. J. (2011). The difficulties faced by advanced Iraqi foreign learners in passing ITP TOEFL test. Journal of Basrah Researches (Humanities Series), 36(4), 110-138.

Alderson, J.C. (2000). Success in English Teaching. New York: Oxford University Press.

Alghail, A.A.A. \& Mahfoodh, O.H.A. (2016). Academic reading difficulties encountered by international graduate students in a Malaysian university. Issues in Educational Research, 26(3), 369-386.

Ali, H. (2012). The use of silent reading in improving students' reading comprehension and their achievement in TOEFL score at a private English course. International Journal of Basic and Applied Science, 1(1), 47-52.

Aliponga, J. (2013). Reading journal: its benefits for extensive reading. International Journal of Humanities and Social Science, 3(12), 73-80.

Antoni, R. (2014). An analysis on $6^{\text {th }}$ semester students' TOEFL experience at English department of teachers training and education faculty of Pasir Pengaraian
University. Journal Ilmiah Edu Research, 3(1), 9-16.

Ary, D., Jacobs, LC., Sorensen, C., \& Razavieh, A. (2006). Introduction to Research in Education. (7th ed.). Wadsworth: Cengage Learning.

Celce-Murcia, M. (2001). Teaching English as a Second and Foreign Language (Third Edition). Boston: Heinle and Heinle Thomson Learning Inc.

Chawwang, N. (2008). An Investigation of English Reading Problems of Thai $12^{\text {th }}$ Grade Students in Nakhonratchasima Educational Region 1, 2, 3, and 7 (Unpublished Doctoral dissertation) Srinakharinwirot University Bangkok.

Educational Testing Service (ETS). (2010). Test and Score Data Summary for TOEFL Internet-based and Paper-based Tests. Retrieved November 29, 2015 from www.ets.org/toefl.

Fjeldstad, M. C. (1994). The Thoughtful Reader. A whole Language Approach to College Reading. New York: Harcourt Brace \& Company.

Fitriani, S. S. (2015). Improving reading comprehension of Acehnese EFL students. Unpublished Doctoral Dissertation. University of New England: Armidale.

Harrison, C. (2004). Understanding Reading Developement. London: SAGE Publication

Healy, C. (2002). Reading: What the Experts say. Parent Educational Advocacy Training Center. Retrieved September 29, 2016 from http:www.peatc.org

John, W.B., \& James, V.K. (2006). Research in Education, Tenth Edition. Chicago: Pearson Education Inc.

Karbalaei, A. (2010).Iranian EFL and Indian ESL college students, beliefs about reading strategies in L2. Network and Scientific Journals, 12(2), 51-68.

Klinger, J. K.., Vaughn, S., Boardman, A. (2007). Teachimg Reading Comprehension to Students with Learning 
Difficulties. New York: The Guildford Press.

Lems, K., Miller, L. D., \& Soro, T. M. (2010). Teaching Reading to English Language Learners: Insights from Linguistics. New York: The Guilford Press.

Li, Y., \& Wang, C. (2010). An empirical study of reading self-efficacy and the use of reading strategies in the Chinese EFL context. The Asian EFL Journal, 12(2), $144-162$.

Mahmud, M. (2014). The EFL students' problems in answering the test of English as a foreign language (TOEFL): A study in Indonesian context. Theory and Practice in Language Studies, 4(12), 2581-2587.

Nezami, S. (2012). A critical study of comprehension strategies and general problems in reading skill faced by Arab EFL learners with special reference to Najran University in Saudi Arabia. International Journal of Social Sciences and Education, 2(3), 306-316.

Philips, D. (2003). Longman Preparation Course for the TOEFL Test. London: Longman.

Samad, I. A. (2016). Improving Students' Competence in the Thesis Defence

Examination in Two Universities in Aceh, Indonesia. Unpublished Doctoral Dissertation. University of New England: Armidale.

Samad, I. A, Hizir, Kasim,U., Fitriani, S. S., \& Mustafa, F. (2016). Resep Unggulan Unsyiah Meningkatkan Nilai TOEFL. Proceeding of Seminar Nasional Pengembangan Pendidikan Tinggi, 25 October 2016. Padang: $\quad$ Andalas University Press.

Samad, I. A \& Fitriani, S. S. (2016). English Proficiency in Facing ASEAN Economic Community: an Opportunity or a Challenge?. Proceedings of the 6th Annual International Conference Syiah Kuala University (AIC Unsyiah) in conjunction with the 12th International Conference on
Mathematics, Statistics and Its Application (ICMSA), October 4-6, Banda Aceh, Indonesia

Shang, H. F. (2010). Reading strategy use, selfefficacy and EFL reading comprehension. The Asian EFL Journal, 12(2), 18-42.

Snow, C. (2002). Reading for Understanding (Towards an R\&D Programs in Reading Comprehension). Santa Monica: RAND

Warfield, W., Laribee, R., \& Geyer, R. W. (2013). Examining results and establishing benchmark data from the TOEFL ITP test. American Academic \& Scholarly Research Journal,5(3), 191-198. 